\section{Building bridges}

\section{By Tracey Baas, Senior Editor}

Johnson \& Johnson has joined the ranks of funders supporting the California Institute for Quantitative Biosciences Bridging-the-Gap Awards by providing two grants. The company is the first pharma to put money behind the awards.

The Bridging-the-Gap Awards were established in 2007 by the California Institute for Quantitative Biosciences (QB3) and the Rogers Family Foundation, an Oakland-based philanthropic organization. The awards provide up to $\$ 125,000$ for proof-of-concept research and are renewable for a second year, with another allotment of $\$ 125,000$.

Each award includes membership in the QB3 Startup-in-a-Box program, which allows grantees to form a company, a prerequisite when applying for government-sponsored Small Business Innovation Research (SBIR) funds.

QB3 offers these startups small rental laboratory spaces in University of California incubators, dubbed Garages-a nod to oldschool Silicon Valley startups like Apple or Hewlett-Packard.

Through 2011, the Rogers Family Foundation has been the primary funder of the Bridging-the-Gap Awards. It has supported 12 projects. Of those, 5 have resulted in startup companies that have raised a total of $\$ 9$ million and 4 have resulted in partnerships with established companies (see Table 1, "Trajectories of recipients of the California Institute for Quantitative Biosciences' (QB3) Bridging-the-Gap Awards”).

This year, the foundation has funded three proposals.

Johnson \& Johnson, through its Corporate Office of Science \& Technology (COSAT), has funded two projects. One award went to Shuvo Roy, associate professor of bioengineering and therapeutic sciences at the University of California, San Francisco, for research on an artificial pancreas. The other went to Scott Lokey and Matthew Jacobson to design and synthesize orally bioavailable macrocycles that target protein-protein interactions. Lokey is an associate professor of chemistry at the University of California, Santa Cruz, and Jacobson is vice chair and professor of pharmaceutical chemistry at UCSF.

In all cases, proposals are selected by a QB3 scientific committee that includes representatives of all three QB3 campuses-University of California, Berkeley, UCSF and UCSC-plus representatives from Rogers, COSAT and VCs.

According to Jeff Calcagno, senior director of emerging technologies at COSAT, “J\&J COSAT’s funding of QB3's Bridging-the-Gap program is structured as a gift, which is consistent with COSAT's mission of catalyzing early stage external innovation through collaborations that are innovator friendly."

Neena Kadaba, QB3's director of industry alliances, sees COSAT's investment as "a new model for industry, with researchers receiving precommercial support to address potential scientific risks in their technology before launching a startup and with established companies building early relationships with startups as they form."

"If we're working in a collaborative way with these external innovators starting at the early stages of research, then we will potentially become a partner-of-choice for these innovators as creative solutions mature," Calcagno told SciBX.

J\&J did not disclose how many more awards it plans to fund.

\section{On the COSAT wave}

Roy is no newcomer to the QB3 award program. His team won a Bridging-the Gap award in 2010 to develop a prototype of an artificial kidney, and his team has formed a startup to further develop the work toward a product.

His hope is that the team's prior experience with silicon filtration membrane technology will transition from the kidney to the pancreas.

"The Bridging-the-Gap award will allow our team to do key proof-of-concept experiments to make the idea more attractive to investors," Roy told SciBX. "Even though my laboratory has a strong foundation in silicon filtration membrane technology, moving from creating a bioreactor using kidney epithelial cells to pancreatic $\beta$ islet cells is not trivial."

He added: "Being a part of QB3 at UCSF is an advantage because I can interact with a strong and broad group of specialists with skills such as islet cell biology, imaging techniques and transplant surgery that are outside my own realm of expertise. I can actually walk down the hallway and find some of these individuals to have a chat. It's all very collegial and inspiring."

According to Jacobson, the COSAT-backed Bridging-the-Gap award will give him and Lokey an opportunity "to provide the proof-of-concept experiments that will show companies that macrocyclic compounds are a viable therapeutic strategy to treat diseases that have protein-protein interactions to be targeted. Our first experiments will target proteinprotein interactions mediated by $\alpha$-helices, of which there are many."

Although Jacobson and Lokey are newcomers to the Bridging-theGap Awards, they have previously collaborated with Pfizer Inc. under the auspices of QB3, working together to identify key principles to predict pharmacokinetic compound properties, such as oral bioavailability, and to use the principles to design macrocyclic compounds with better membrane permeability and oral bioavailability. ${ }^{1}$

"We are continuing our very productive collaboration with Pfizer to build on our published work with them, while we simultaneously explore other potential applications to other target classes, using the support from the J\&J award," Jacobson told SciBX. 
Table 1. Trajectories of recipients of the California Institute for Quantitative Biosciences' (QB3) Bridging-the-Gap Awards.

\begin{tabular}{|c|c|c|c|c|}
\hline Principal investigator & QB3 campus & Award year & Project & Status \\
\hline Tejal Desai & $\begin{array}{l}\text { University of California, } \\
\text { San Francisco }\end{array}$ & 2007 & $\begin{array}{l}\text { Microengineered particles for oral delivery of } \\
\text { chemotherapeutics }\end{array}$ & $\begin{array}{l}\text { Partnered and licensed technology to Zcube } \\
\text { s.r.l., a unit of Zambon Co. S.p.A. }\end{array}$ \\
\hline Michael Marletta & $\begin{array}{l}\text { University of California, } \\
\text { Berkeley }\end{array}$ & 2007 & $\begin{array}{l}\text { Engineer H-NOX (heme nitric oxide/oxygen } \\
\text { binding)-family proteins for therapeutic delivery } \\
\text { of oxygen and nitric oxide }\end{array}$ & $\begin{array}{l}\text { Founded Omniox Inc. in QB3 Garage and } \\
\text { raised more than } \$ 4 \text { million in Small Business } \\
\text { Innovation Research (SBIR) funding }\end{array}$ \\
\hline Amy Herr & UCBerkeley & 2008 & $\begin{array}{l}\text { Rapid autoantibody profiling for systemic } \\
\text { lupus erythematosus (SLE) using micro- and } \\
\text { nanotechnology }\end{array}$ & $\begin{array}{l}\text { Partnered and licensed technology to an } \\
\text { undisclosed, international life sciences } \\
\text { company }\end{array}$ \\
\hline Brian Shoichet & UCSF & 2009 & $\begin{array}{l}\text { Chemoinformatic and statistical methods to } \\
\text { uncover links between drugs and the biological } \\
\text { targets responsible for disease }\end{array}$ & $\begin{array}{l}\text { Founded SeaChange Pharmaceuticals Inc. in } \\
\text { QB3 Garage }\end{array}$ \\
\hline Jim Wells & UCSF & 2009 & Apoptotic biomarkers for hematologic cancers & Unpartnered \\
\hline Tejal Desai & UCSF & 2009 & $\begin{array}{l}\text { Titania nonporous membranes for constant- } \\
\text { rate interferon- } \alpha \text { (IFNA; IFN- } \alpha \text { ) delivery to } \\
\text { treat HCV }\end{array}$ & $\begin{array}{l}\text { Founded Nano Precision Medical Inc. in QB3 } \\
\text { Garage; now at QB3 East Bay Innovation } \\
\text { Center }\end{array}$ \\
\hline Charles Chiu & UCSF & 2010 & $\begin{array}{l}\text { Pan-viral clinical diagnostic for respiratory and } \\
\text { diarrheal illness }\end{array}$ & Partnered with Akonni Biosystems Inc. \\
\hline Shuvo Roy & UCSF & 2010 & $\begin{array}{l}\text { Wearable hemofiltration device for renal } \\
\text { replacement }\end{array}$ & Forming startup \\
\hline Holger Schmidt & $\begin{array}{l}\text { University of California, } \\
\text { Santa Cruz }\end{array}$ & 2010 & $\begin{array}{l}\text { Portable, amplification-free virus detector using } \\
\text { optofluidic chips }\end{array}$ & $\begin{array}{l}\text { Founded LiquiLume Diagnostics Inc. at the } \\
\text { San Jose BioCenter }\end{array}$ \\
\hline Charles Craik & UCSF & 2011 & $\begin{array}{l}\text { Noninvasive imaging of cancer by targeting } \\
\text { active proteases and their receptors }\end{array}$ & Two industry partnerships under negotiation \\
\hline Tejal Desai & UCSF & 2011 & $\begin{array}{l}\text { Nanostructural biopolymer films for retinal } \\
\text { drug delivery }\end{array}$ & Forming startup \\
\hline $\begin{array}{l}\text { John Kuriyan; } \\
\text { Art Weiss }\end{array}$ & UCBerkeley; UCSF & 2011 & $\begin{array}{l}\text { Discover inhibitors of the catalytic activity } \\
\text { of the T cell receptor (TCR) tyrosine kinase } \\
\text { ZAP70 ( } \zeta \text {-chain (TCR) associated protein } \\
\text { kinase } 70 \mathrm{kDa})\end{array}$ & Unpartnered \\
\hline Adam Abate & UCSF & 2012 & $\begin{array}{l}\text { Microfluidic device to analyze rare circulating } \\
\text { tumor cells }\end{array}$ & $\begin{array}{l}\text { Founded Torrent Bio Inc. in Redwood Shores, } \\
\text { Calif. }\end{array}$ \\
\hline $\begin{array}{l}\text { Roger Linington; } \\
\text { Fitnat Yildiz }\end{array}$ & UCSC & 2012 & $\begin{array}{l}\text { Biofilm inhibitors as therapeutics for surface- } \\
\text { associated bacterial infection }\end{array}$ & Unpartnered \\
\hline Trever Bivona & UCSF & 2012 & $\begin{array}{l}\text { Systematic discovery of rational, molecularly } \\
\text { targeted cancer polytherapies }\end{array}$ & Unpartnered; clinical trials starting \\
\hline $\begin{array}{l}\text { Matthew Jacobson; } \\
\text { Scott Lokey }\end{array}$ & UCSF; UCSC & $2012^{\mathrm{A}}$ & $\begin{array}{l}\text { Discovery platform for orally bioavailable } \\
\text { inhibitors of therapeutically relevant protein- } \\
\text { protein interactions }\end{array}$ & Unpartnered \\
\hline Shuvo Roy & UCSF & $2012^{\mathrm{A}}$ & $\begin{array}{l}\text { Intravascular capsule of pancreatic b islet cells } \\
\text { to treat type } 1 \text { diabetes }\end{array}$ & Unpartnered \\
\hline
\end{tabular}

${ }^{\text {A}}$ First set of projects funded by the Johnson \& Johnson Corporate Office of Science \& Technology (COSAT).

Whereas J\&J is the first pharma to participate in the Bridgingthe-Gap Awards, it is not the first to work with QB3. In 2008, QB3 partnered with Pfizer's External R\&D Innovation (ERDI) center to foster collaborative projects and programs for sponsored research agreements, material transfers and scientist exchanges.

In March, the parties extended the deal by three years, through 2014. The agreement includes a program to fund postdoctoral research that has a direct impact on Pfizer's R\&D. Pfizer may also provide seed funding for startup companies spun out of QB3.

Baas, T. SciBX 5(18); doi:10.1038/scibx.2012.456 Published online May 3, 2012

\section{REFERENCES}

1. White, T.R. et al. Nat. Chem. Biol. 7, 810-817 (2011)

\section{COMPANIES AND INSTITUTIONS MENTIONED}

California Institute for Quantitative Biosciences, San Francisco, Calif.

Johnson \& Johnson (NYSE:JNJ), New Brunswick, N.J.

Pfizer Inc. (NYSE:PFE), New York, N.Y.

Rogers Family Foundation, Oakland, Calif.

University of California, Oakland, Calif.

University of California, Berkeley, Calif.

University of California, San Francisco, Calif.

University of California, Santa Cruz, Calif. 